\title{
TRACKING THE IMPLEMENTATION GAP: EMPIRICALLY ASSESSING THE TRANSLATION OF INTERNATIONAL ANTISLAVERY COMMITMENTS IN DOMESTIC LEGISLATION GLOBALLY
}

\author{
KATARINA SCHWARZ* AND JEAN ALLAIN**
}

\section{TABLE OF CONTENTS}

I The Challenges of International Law in Prohibiting Slavery 160

II Mapping Implementation of International Commitments to Prohibit Human Exploitation

III Conclusions: The Value of Mapping Domestic Implementation of International Commitments

The prohibition against slavery in international law is unique in several significant ways. First, it has been recognised by the International Court of Justice as a jus cogens norm carrying obligations erga omnes. ${ }^{1}$ That is to say, it is a norm of international law binding on all states, from which no derogation is permissible and violation of which attracts the legal interest of the international community as a whole entailing an obligation to cooperate to bring such a breach to an end. ${ }^{2}$ Second, it represents the first universal effort enshrined in international law to influence the domestic legislation of all states on a normative question. ${ }^{3}$ Third, it is often seen as the first global human rights movement and the root of international human rights law, centring the concept of individual human dignity within the traditionally statist constructs of international law. ${ }^{4}$ And finally, given its importance at the international level, it is often presumed that its prohibition at the domestic level is already complete everywhere.

* The Rights Lab, University of Nottingham, UK.

** Faculty of Law, Monash University, Australia; Wilberforce Institute, University of Hull, UK.

1 Case Concerning the Barcelona Traction, Light and Power Company Ltd (Belgium v Spain) (Judgment) [1970] ICJ Rep 3, 32 [34].

2 On the implications of this status, see Jean Allain, 'Slavery and Its Obligations Erga Omnes' (2019) 36(1) The Australian Year Book of International Law 83.

3 This occurred in international instruments adopted in the early twentieth century in relation to both slavery and the slave trade, and the so-called 'white slave traffic'. See International Agreement for the Suppression of the White Slave Traffic, opened for signature 4 May 1910, 1 LNTS 83 (entered into force 18 July 1905) art 3; Slavery Convention, opened for signature 25 September 1926, 60 LNTS 253 (entered into force 9 March 1927) art 6 ('1926 Slavery Convention').

4 See Jenny S Martinez, The Slave Trade and the Origins of International Human Rights Law (Reprint edn, Oxford University Press 2014). 
For decades, antislavery actors - scholars, governments and activists - have asserted that slavery has already been made illegal in every country in the world. ${ }^{5}$ However, this understanding of slavery's universal domestic illegality represents an erroneous assumption based on a misunderstanding of its definition, revealing something far less unique about the prohibition of slavery: an ongoing struggle to achieve in practice the domestic implementation of a norm agreed to in principle at international law. ${ }^{6}$ Although the international norms are designed to protect individuals from abuse, and to ensure that every person receives this protection through citizenship in a state, this does not always pan out in reality. By mapping all United Nations member states' international commitments and domestic legislation related to slavery, we not only reveal the current realities of domestic implementation, but also provide a vital tool for advocates seeking to address ongoing limitations in states' domestication of international law in this area. ${ }^{7}$

\section{The Challenges of International LaW in ProhiBiting SLAVERY}

In general, states make a multitude of international commitments, pledging themselves at the international level to refrain from, and engage in, a variety of different behaviours and making themselves accountable to other states for actions contravening these frameworks. Traditionally, these obligations concerned and regulated only states' interactions with one another. International law had no place interfering with the sovereignty of states to act as they saw fit within their own borders, and the individual had no place in the international legal system, except in a limited sense as representatives or agents of the state and in their ability to act on behalf of their citizens abroad. ${ }^{8}$ However, beginning with the antislavery instruments, and carrying through to the development of human rights law, international law began to concern itself both with the way states acted within their own territories and jurisdiction, and with individuals as subjects of international law benefiting from limited rights and duties.

Antislavery treaties represented a step-change in international law, requiring states take legislative action to address a practice occurring within their own borders (slavery) and not only transnationally (international slave trade). However, despite states undertaking explicit obligations to ensure their domestic laws captured the prohibitions against human exploitation, practice in this regard remained scarce. The fundamental premise of states' sovereignty within their own territories continued to underpin the international legal system. Yet, accountability for these commitments in the international arena required states intervene in other

5 See, eg, 'Modern-Day Slavery', New York Times (online, 9 September 2000) $<$ https://www.nytimes.com/2000/09/09/opinion/modern-day-slavery.html>; Nita Bhalla, 'What Can Governments do to Prevent Slavery?', World Economic Forum (online, 21 October 2015) <https:/www.weforum.org/agenda/2015/10/what-can-governments-do-toprevent-slavery/>; 'Ethics Guide: Modern Slavery' $B B C$ (Web Page) $<$ http://www.bbc.co.uk/ethics/slavery/modern/modern_1.shtml $>$.

6 See Katarina Schwarz and Jean Allain, Antislavery in Domestic Legislation: An Empirical Analysis of National Prohibition Globally (Report, Rights Lab and Castan Centre for Human Rights Law February 2020) <https://antislaverylaw.ac.uk/resources/summary-of-findings/>.

7 This paper is based on a new database of international commitments and domestic legislation created by the authors - Katarina Schwarz and Jean Allain, Antislavery in Domestic Legislation (Database, 12 February 2020) <https://antislaverylaw.ac.uk $>$. All data and conclusions on domestic law are drawn from this dataset.

8 See generally Bardo Fassbender, Daniel Högger and Anne Peters (eds), The Oxford Handbook of the History of International Law (Oxford University Press 2012) 27. 
states' domestic affairs, creating tensions between commitment and enforcement that provided the preconditions for a substantial implementation gap.

\section{MAPPING IMPLEMENTATION OF INTERNATIONAL COMMITMENTS TO}

\section{ProhiBIT HuMAN EXPLOITATION}

Through the twentieth century, states undertook specific antislavery commitment, writ large, to criminalise slavery and the slave trade, ${ }^{9}$ forced labour, ${ }^{10}$ institutions and practices similar to slavery, ${ }^{11}$ servitude, ${ }^{12}$ and trafficking in persons. ${ }^{13}$ However, without comprehensive and systematic research tracking and assessing compliance with these obligations across member states, very little evidence existed of the extent to which the international community of states had implemented these commitments domestically. This allowed the myth of slavery's universal domestic illegality to continue unchallenged, shifting focus away from the fundamental legislative reforms needed to prohibit human exploitation within states.

To assess the extent to which antislavery commitments (as well as commitments concerning related forms of human exploitation) enshrined in international law are prohibited at the domestic level, we compiled the nationallevel legislation of all $193 \mathrm{UN}$ member states relevant to the prohibition of slavery, servitude, forced labour, institutions and practices similar to slavery, forced labour and trafficking in persons to create the Antislavery in Domestic Legislation database. ${ }^{14}$ From over 1000 domestic statutes, we analysed thousands of provisions to establish the extent to which each state had prohibited these forms of exploitation and satisfied their international obligations. Analysis of domestic legislation across the world's countries revealed widespread gaps in states' efforts to fulfil a basic requirement of treaties addressing human exploitation: prohibition

9 Obligations to prohibit slavery are found in the 1926 Slavery Convention (n 3); Supplementary Convention on the Abolition of Slavery, the Slave Trade, and Institutions and Practices Similar to Slavery, opened for signature 7 September 1956, 266 UNTS 3 (entered into force 30 April 1957) ('1956 Supplementary Convention'); International Covenant on Civil and Political Rights, opened for signature 16 December 1966, 999 UNTS 171 (entered into force 23 March 1976) ('ICCPR'). Other relevant regional human rights instrument include: African Charter on Human and Peoples' Rights, opened for signature 27 June 1981, OAU Doc $\mathrm{CAB} / \mathrm{LEG} / 67 / 3$ rev 5 (entered into force 21 October 1986) ('African Charter'); American Convention on Human Rights, opened for signature 22 November 1969, OAS TS 36 (entered into force 18 July 1978) ('American Convention'); European Convention on Human Rights, opened for signature 4 November 1950, ETS 9 (entered into force 3 September 1953) ('European Convention').

10 Obligations to prohibit forced labour are found in the Convention (No 29) Concerning Forced or Compulsory Labour, As Modified by the Final Articles Revision Convention, 1946, opened for signature 28 June 1930, 39 UNTS 55 (entered into force 1 May 1932) ('1930 Forced Labour Convention'). See also African Charter (n 9); American Convention (n 9); European Convention (n 9).

11 Namely, serfdom, debt bondage, practices involving the transfer of women in the context of marriage and delivery of children for exploitation: 1956 Supplementary Convention (n 9) art 1.

12 Obligations to prohibit servitude are found in the ICCPR (n 9). See also African Charter (n 9); American Convention (n 9); European Convention (n 9).

13 Obligations to prohibit trafficking are found in a variety of conventions addressing trafficking, culminating in the Protocol to Prevent, Suppress and Punish Trafficking in Persons, Especially Women and Children, Supplementing the United Nations Convention against Transnational Organized Crime, opened for signature 15 November 2000, 2237 UNTS 319 (entered into force 25 December 2003) ('Palermo Protocol').

14 Schwarz and Allain (n 7). 
and criminalisation. This is despite the fact that all states have obligations to prohibit slavery under customary international law, and the vast majority have undertaken treaty commitments to prohibit the various practices under consideration.

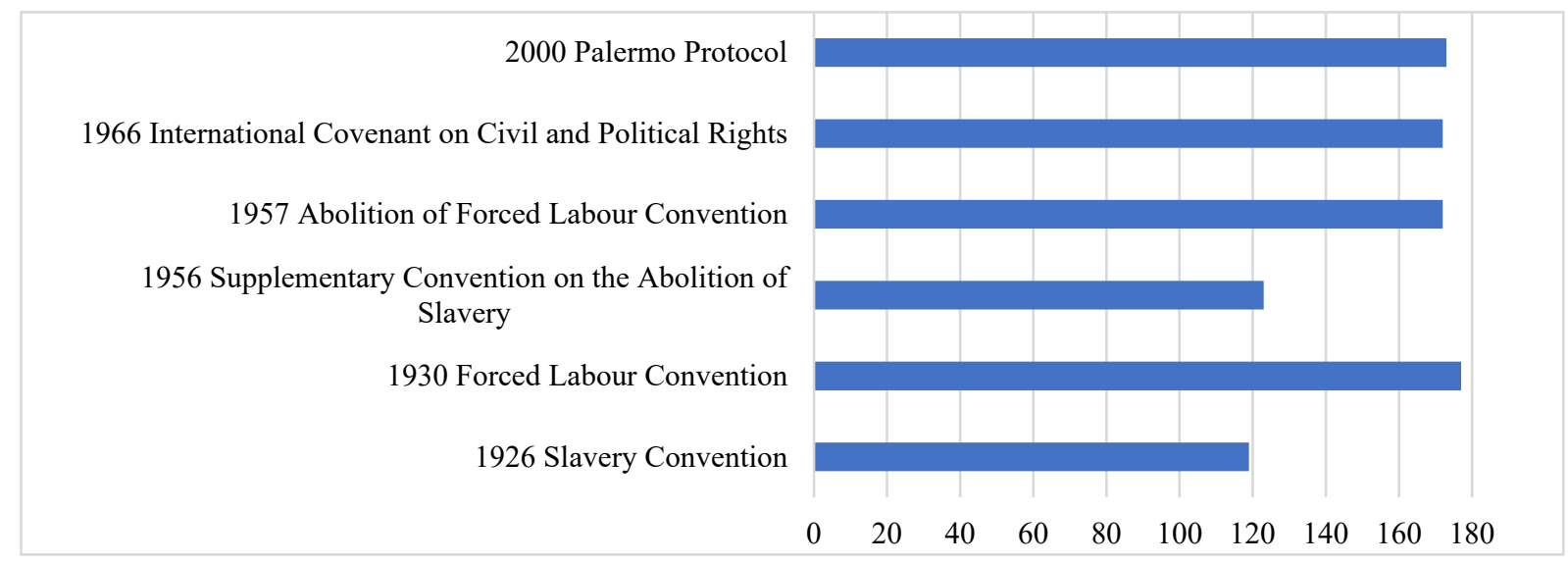

Figure 1. Number of UN member states $(n=193)$ party to the core international instruments addressing human exploitation. ${ }^{15}$

Globally, almost all UN member states have ratified at least one of the core international instruments addressing human exploitation (see Figure 1). Overall, only 3 states $(2 \%)$ do not have specific treaty obligations to prohibit any one of these practices (Bhutan, Tonga and Tuvalu), while 113 states (59\%) are required to prohibit all five. ${ }^{16}$ Several of these core instruments address multiple forms of exploitation. The above ratifications therefore translate to $96 \%$ of states having obligations to prohibit forced labour, $95 \%$ with treaty-based obligations to prohibit slavery, $91 \%$ with obligations regarding trafficking in persons, $89 \%$ for servitude and $64 \%$ for institutions and practices similar to slavery. ${ }^{17}$

Despite near universal commitment to treaties requiring the criminalisation of human exploitation in its various forms, many states have yet to enact domestic legislation creating such offences. Of all 193 UN member states, 99 (51\%) have enacted criminal legislation prohibiting slavery or the slave trade, $13(7 \%)$ have enacted legislative provisions concerning servitude, $23(12 \%)$ have criminalised the institutions and practices similar to slavery and $81(42 \%)$ have penal provisions in place for the punishment of forced labour (see Figure 2). ${ }^{18}$ With respect to each of these practices, a significant implementation gap between international commitment and domestic legislation is evident. The prohibition of trafficking in persons has experienced a more complete translation from international to domestic law, with 185 states $(96 \%)$ having created domestic criminal offences of trafficking. ${ }^{19}$ However, this translation is far from perfect. Many states' trafficking

15 Palermo Protocol (n 13); ICCPR (n 9); Convention (No 105) Concerning the Abolition of Forced Labour, opened for signature 25 June 1957, 320 UNTS 291 (entered into force 17 January 1959) ('1957 Abolition of Forced Labour Convention'); 1956 Supplementary Convention (n 9); 1930 Forced Labour Convention (n 9); 1926 Slavery Convention (n 3).

16 Schwarz and Allain (n 6) 8.

17 ibid 9.

18 ibid 11.

19 ibid. 
offences fail to satisfy the obligations contained in the Palermo Protocol, failing to capture every element of the Palermo Protocol definition of trafficking. ${ }^{20}$

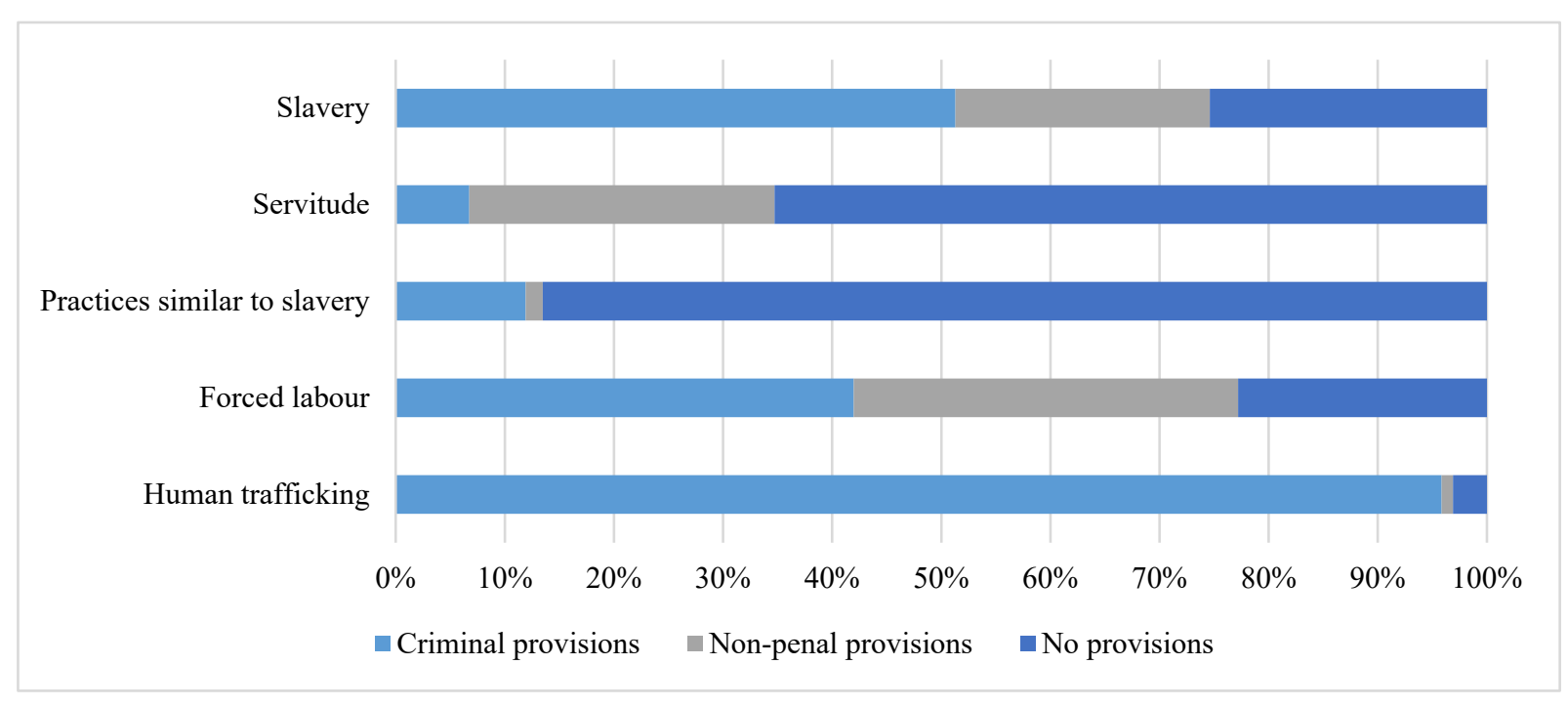

Figure 2. States' domestic legislation prohibiting human exploitation.

Analysis of states' domestic legislation against a variety of factors reveals trends not only in which states have enacted domestic prohibition, but in how they go about doing so. For instance, statistical analysis shows statistically significant variation between different geographic regions in the approach taken to prohibition (see Figure 3). ${ }^{21}$ Latin American and Caribbean Countries are more likely to adopt constitutional prohibitions, while countries in the Western European and Others group are significantly less likely to do so. On the other hand, Latin American and Caribbean countries are statistically less likely to have enacted criminal sanctions, while African states are the most likely to have done so. These findings tell us about different countries' approaches to enacting prohibition in their domestic law. By highlighting both gaps that need to be addressed, and contextual preferences, the global analysis begins to support a more evidence-based approach to advocacy for enactment and reform of provisions prohibiting human exploitation. Closer analysis of the terms of these provisions provides an even more nuanced picture of how different states (and different kinds of states) legislate prohibition.

20 It appears that only 8 of the 175 states party to the Palermo Protocol (n 13) have fully aligned their domestic offence provisions with the Palermo Protocol, although in some cases the different construction creates a more encompassing definition: Schwarz and Allain (n 7) 23.

21 Schwarz and Allain (n 6) 12-13. Regional groupings reflect the geopolitical grouping of United Nations member states as opposed to a purely geographic grouping. See UN Department for General Assembly and Conference Management, 'United Nations Regional Groups of Member States', United Nations (Web Page) $<$ https://www.un.org/depts/DGACM/RegionalGroups.shtml $>$. All special cases are allocated to a regional grouping, with Kiribati assigned to Asia-Pacific and Israel, Turkey and the United States assigned to Western Europe and Others. 


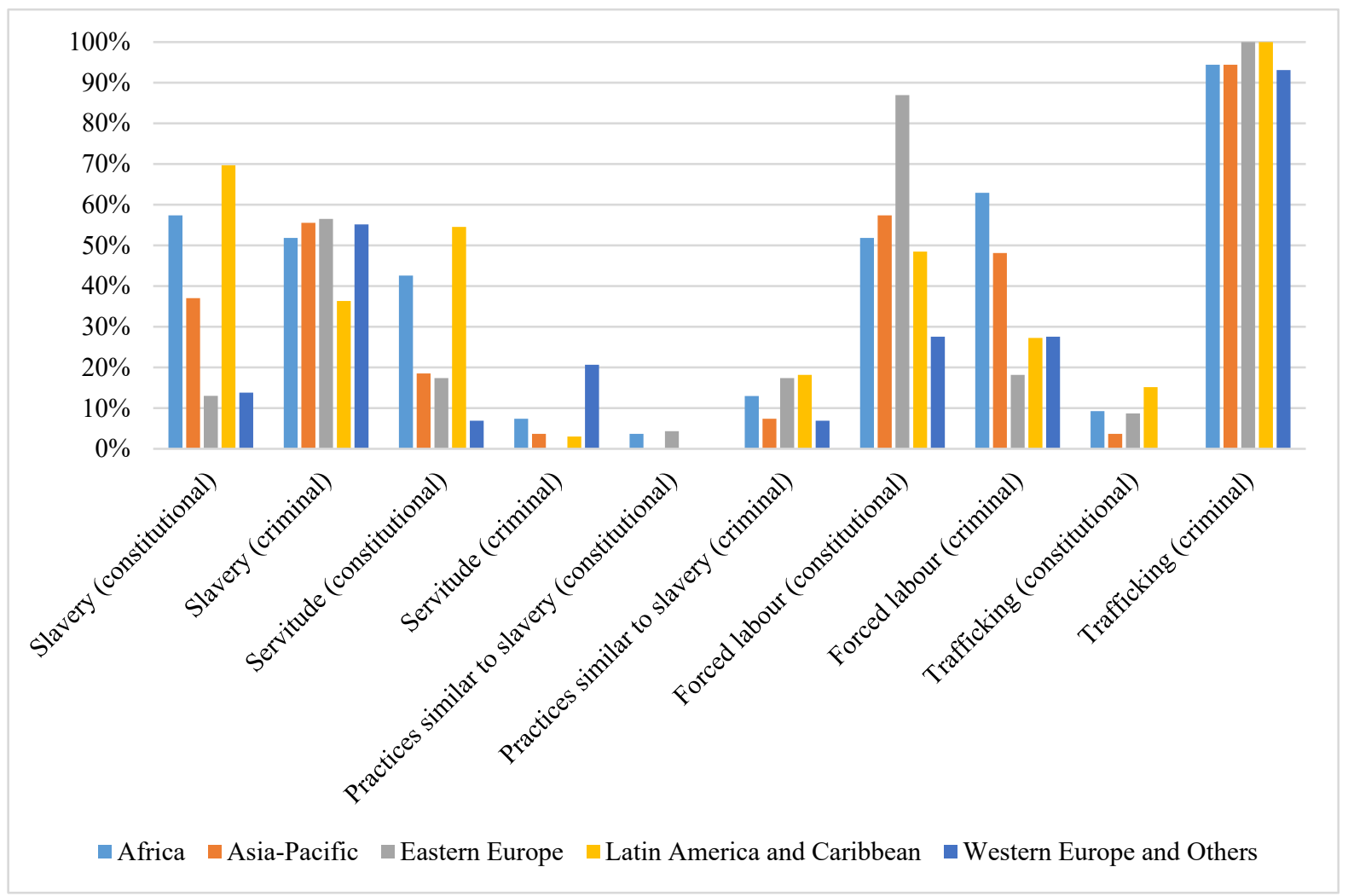

Figure 3. Proportion of states with domestic provisions by region.

Global statistical analysis also sheds light on the relationship between ratification of international treaties obliging states to criminalise human exploitation and domestic legislative efforts implementing such. Many international jurists operate from the premise that 'almost all nations observe almost all principles of international law and almost all of their obligations almost all of the time'.22 However, the evidence of such remains ambiguous, and may diverge substantially between different branches of international law and between states. With regard to international human rights treaties, the question of whether ratification results in improved protection of human rights within states depends on a plethora of factors which cannot be distilled into a set of generalised observations or conclusions. However, debates over the efficacy of human rights treaties in effecting change continue. Having conducted both statistical and case analyses, Beth Simmons argues that, on average, ratification of human rights treaties produces positive improvements in the protection of rights in practice. ${ }^{23}$ However, Emilie Hafner-Burton and Kiyoteru Tsutsui contend that, although human rights instruments may be 'effective in stable and consolidating democracies with strong civil society activism', they generally fail to effect meaningful change in the most repressive and rights-abusing states where change

22 Louis Henkin, How Nations Behave: Law and Foreign Policy ( $2^{\text {nd }}$ edn, Columbia University Press 1979) 47.

23 Beth A Simmons, Mobilizing for Human Rights: International Law in Domestic Politics (Cambridge University Press 2009). 
is needed most. ${ }^{24}$ Heather Smith-Cannoy further observes that although 'governments are quite willing to sign their names on the dotted line and send human rights treaties through the domestic ratification process, this readiness to commit has not yet translated into improved respect for human rights'.25 Importantly, the mechanisms of enforcement and compliance are significantly distinct in the context of human rights compared with, for instance, international investment law. ${ }^{26}$ States themselves have less incentive to enforce compliance with human rights law where violations have no tangible connection to their own interests or citizens (as is often the case).

The fundamental and jus cogens nature of the prohibition against slavery speaks to an increased impetus for domestic action implementing states' international commitments. Yet, only half of all states have enacted domestic criminal prohibition. In fact, across the five extreme forms of human exploitation considered, there is no statistically significant correlation between international obligations and domestic action. In other words, signing up to an international treaty on the subject does not make a state (statistically) more likely to enact domestic legislation giving effect to its obligations under that treaty (see Figure 4). ${ }^{27}$ This does not imply that treaty ratification does not influence particular states in enacting and reforming domestic provisions prohibiting exploitation. Rather, it demands closer consideration of each state, to consider the factors contributing to, and inhibiting domestic legislative action.

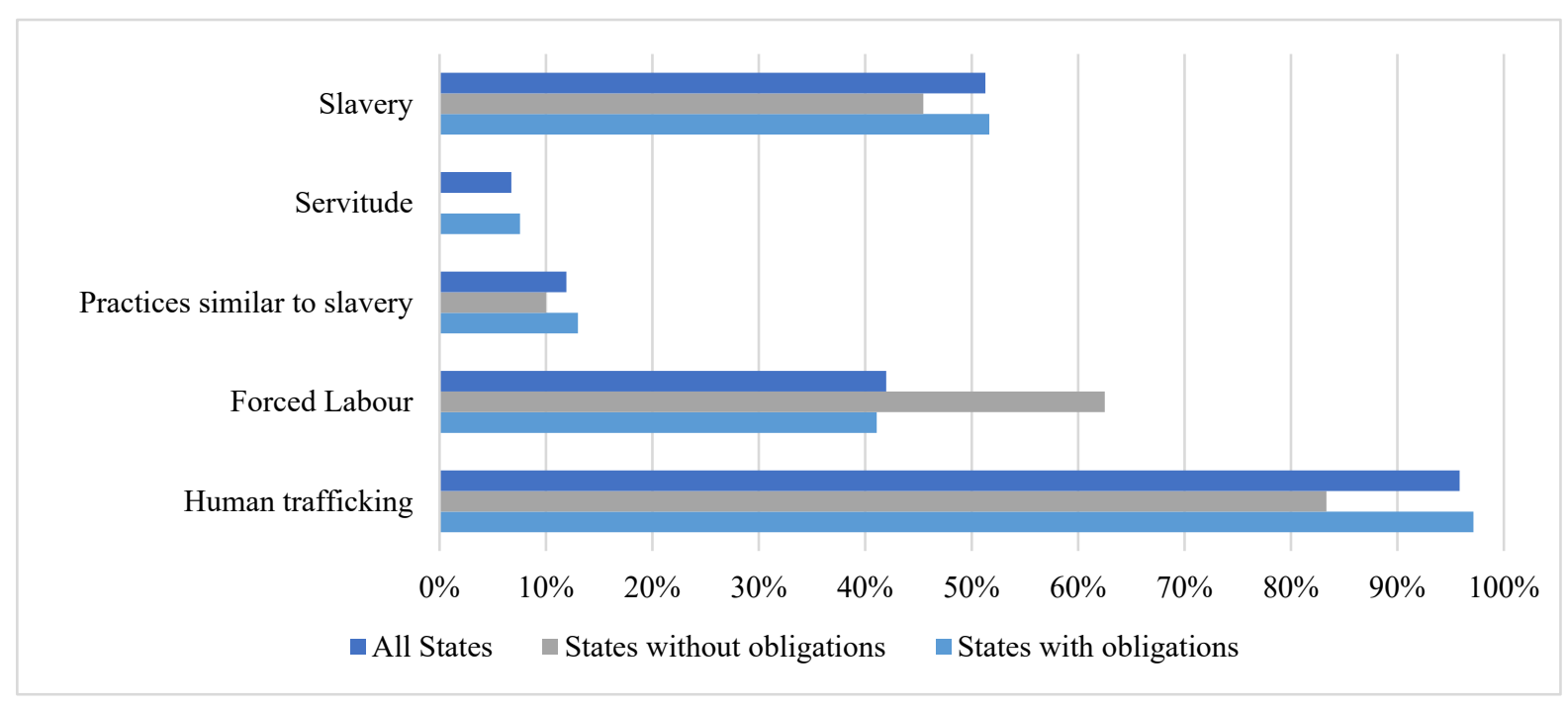

Figure 4. Proportion of states with domestic provisions by treaty obligations.

24 Emilie Hafner-Burton and Kiyoteru Tsutsui, 'Justice Lost! The Failure of International Human Rights Law to Matter Where Needed Most' (2007) 44(4) Journal of Peace Research 407.

25 Heather Smith-Cannoy, Insincere Commitments: Human Rights Treaties, Abusive States, and Citizen Activism (Georgetown University Press 2012) 1.

26 Oona Hathaway, 'Do Human Rights Treaties Make a Difference?' (2002) 111(8) The Yale Law Journal 1935, 1938.

27 Schwarz and Allain (n 6) 13. 


\section{Conclusions: The VAlue of MAPPING DOMESTIC IMPLEMENTATION OF}

\section{INTERNATIONAL COMMITMENTS}

Mapping domestic implementation of states' international antislavery commitments reveals a significant implementation gap between international and domestic law in this area. By identifying this misalignment between principle and practice, highlighting where shortcomings exist and how other states have gone about addressing the issue, it provides impetus and evidence for advocacy. It suggests that something more is needed to effect necessary change within states than international commitment, without concluding that the frameworks of international law are irrelevant or unnecessary. Rather, they provide a crucial authoritative yardstick for assessing state practice, as well as a lever for change. In developing a new global dataset of states' domestic legislation, and making this publicly available, this mapping exercise also provides meaningful evidence for a wide range of stakeholders, allowing them to access, analyse and compare global legislative data.

Beyond consideration of extreme forms of exploitation, the Antislavery in Domestic Legislation database provides a window into global and regional trends, as well as national practice, in implementing fundamental international commitments for the protection of individuals at the domestic level. It supports identification of the factors that contribute to, and inhibit, the translation of some of the most fundamental human rights commitments made by states. These lessons extend beyond the domain of antislavery, with relevance for the range of international commitments made by states to protect individuals - including the critical threshold consideration of individuals' right to a nationality that provides access to a plethora of other rights. By enriching the evidence available on why states do, and do not, fulfil their international commitments through national legislation, this research provides insights for those seeking to understand states' approach to international commitments to protect individuals - including the basic protections of nationality and citizenship. The research and analysis of the database further provides methodological insights for the interrogation of domestic implementation of international commitments, and global mapping of the translation of principle in practice. ${ }^{28}$

States make a multitude of international commitments, many of which are fundamental to improving the lives of the world's most vulnerable people. Yet, mechanisms of enforcement and compliance in international law can be imperfect. Knowledge gaps and misinformation exacerbate these difficulties, preventing effective, evidence-based advocacy. By mapping states' domestic implementation of these commitments, we not only reveal whether states have lived up to their commitments, but also provide useful evidence for advocacy and accountability. This data goes beyond answering the question of whether states have implemented their international commitments, to help address the (perhaps more critical) questions of what influences implementation, and how it can be improved.

28 The authors welcome communication from others considering undertaking such a task, with queries to be directed to Katarina.Schwarz@nottingham.ac.uk. 